\title{
Tract of Goll
}

National Cancer Institute

\section{Source}

National Cancer Institute. Tract of Goll. NCI Thesaurus. Code C33799.

A bundle of axon fibers and a sensory (ascending) tract in the dorsal column of the spinal cord that lies medial to the cuneate fasciculus (above the mid-thoracic region), which transmits information from the lower half of the body. 